УдК 378.147: 577.3

DOI 10.31494/2412-9208-2021-1-3-181-189

\title{
ANALYSIS OF THE DEVELOPMENT OF A COMPETENT APPROACH IN THE SYSTEM OF HIGHER VOCATIONAL EDUCATION OF UKRAINE
}

\section{АНАЛІЗ РОЗВИТКУ КОМПЕТЕНТІСНОГО ПІДХОДУ В СИСТЕМІ ВИЩОЇ ПРОФЕСІЙНОÏ ОСВІТИ УКРАЇНИ}

\author{
Tetyana STROGONOVA, \\ Candidate of Economical Sciences, \\ Associate Professor \\ Тетяна СтРОГОНОВА, \\ кандидат економічних наук, \\ доцент \\ strogonova@meta.ua \\ https://orcid.org/0000-0001-5510-2176 \\ Zaporizhzhya State medical \\ University \\ 26, Maiakovskyi avenue, \\ Zaporizhzhya, 69035 \\ Natalia STUCHINSKAYA, \\ Doctor of Pedagogical Sciences, \\ Professor \\ Запорізький державний медичний \\ університет \\ $\triangle$ пр. Маяковського 26, \\ Запоріжжя, 69035 \\ Наталія СТУЧИНСЬКА, \\ доктор педагогічних наук, \\ профресор \\ nvstuchynska@gmail.com \\ https://orcid.org/0000-0002-5583-899X \\ Bogomolets National Medical \\ University \\ Національний медичний \\ університет імені \\ О. О. Богомольия
}

34, Pobeda avenue, Kyiv, $01601 \square$ пр. Перемоги, 34, м.Київ, 01601 Original manuscript received: October 07, 2021

Revised manuscript accepted: December 15, 2021

\section{ABSTRACT}

The article investigates the development of the competence approach in the system of higher professional education of Ukraine. To specify the content of the concepts of "competence» and "competence» in the framework of this approach in the pedagogical field in Ukraine used the method of comparative historical analysis. Using this method, the works of domestic scientists in the period of formation of the competence approach in Ukrainian pedagogy are analyzed. The works of Ukrainian scientists who worked in various fields of knowledge: philology, management, theory of management and personnel management, law, pedagogy are considered. The chronology of the emergence of the concept of "competence» in Western scientific thought, its development and transformation into an educational standard. For an in-depth understanding of the concept of "competence», the process of appearance of the term in the regulatory framework of Ukraine, the genesis of its transformation into a standard of higher education in the domestic field is analyzed. The structure of qualification levels of the National Qualifications Framework is described. The main descriptors of the National Qualifications Framework are defined: knowledge, skills (cognitive and practical), communication, autonomy and responsibility, integral competence. The article mentions the comparison of the system of descriptors of the Ukrainian National Qualifications Framework with the European 
Qualifications Framework for lifelong learning, with the Qualifications Framework of the European Higher Education Area. integral competence The essence of competences and competences as components of the description of qualifications in the National Qualifications Framework is revealed. Differences of competences from the previous indicators of assessment of quality of training are allocated. The peculiarities of integral competencies are defined as those that reflect the ability of a person with a qualification of a certain level to perform tasks and solve problems of a certain level of complexity in the learning process or in professional activities. General competencies are considered as tools for assessing the maturity of the individual, his opportunities for self-improvement and growth. It is emphasized that professional readiness and professional suitability should be established with due regard to the moral and value qualities of the individual. General competencies are offered. which can improve professional selection and positively influence the development of the healthcare sector.

Key words: competence, competencies, higher education, learning outcomes, competence approach, national qualifications framework, sectoral qualifications framework.

Вступ. Компетентісний підхід у системі освіти України фрормувався протягом останніх 30 років та з 2018 р. є одним із освітніх стандартів. Цьому передував довгий період творчого пошуку українських учених-педагогів теоретичних викладів, практичних знахідок, становлення методик. У цей час не припинялися дискусії щодо сутності базових понять компетентісної освіти. У період її становлення, вітчизяні науковці вивчали досвід західних учених та намагались визначити сутність понять компетенція та компетентність, описати множину компетенцій. Період з 2000 по 2015 р. можна назвати експериментальним. Найбільш численними були роботи педагогів-філологів. Теоретичним та методичним проблемам навчання іноземних та рідної мови, вивчення закономірностей і принципів навчання мови взагалі, методиці формування мовних компетенцій було присвячено роботи таких учених, як Ю. Федусенко, Н. Жданова, Н. Коломієць, І.Гудзик, О. Палій, В. Осідак, В. Луценко, Т. Вдовіна, О. Конотоп, Т. Ганічева, Г. Бондаренко, О. Кіршова, О. Каменський, О. Бирюк, Н. Білоножко, В. Перлова, Н. Голуб, З. Бакум, Л. Морська, О. Паршикова, О. Петращук, О. Бігич, О. Ісаєва, О. Вовк.

Пов'язані 3 мовними, соціокультурні та культурологічні компетентності, що з'явились в роботах О. Коломінової, М. Писанко, І. Ковалинської, Н. Голуб, Л. Маслак, Т. Колодько, Н. Мороз були одним із нових напрямів досліджень у педагогічній науці. Проблеми фрормування комунікативних компетенції найшли відображення в роботах педагогів В. Жулкевської, К. Глушенко, Л. Чулкової, А. Курінної, К. Касярум, О. Волченко, Т. Дементьєвої, О. Павленко, К. Балабанової, Ю. Федоренко.

Дослідження сутності та методик формування інтерпретаційної компетенції, управлінських компетенцій, організаційної компетентності, інформаційно-технологічної компетенції можна знайти в роботах А. Вітченко, С. Пільова, Н. Яциніна, Н. Андрущенко. Цікаві роботи С. Кульбіди, М. Фоміної, Т.Дрожжиної знаходились у площині психологічних досліджень та спрямовані на вивчення сутності конфрліктологічної компетенції, психолого-педагогічних компетенцій та таких, що задіяні в інклюзивному навчанні. За цей період педагогами 
С. Шмалєй, . Рудишин, М. Вачевський, Л. Тархан, С. Касярум, Н. Логінова, Н. Болюбаш, К. Осадча було проведено різноманіття досліджень, присвячених професійним компетенціям екологів, біологів, інженерів, маркетологів, економістів, юристів, програмістів.

Проблему формування та розвитку компетентностей учнів на рівні фрізичної та математичної компетентності досліджували вчені П. Атаманчук, В. Ачкан, Г. Бібік, Л. Благодаренко, М. Головань, В. Заболотний, І. Зіненко, Н. Єрмакова, С. Раков, Л. Романишина, М. Садовий, О. Співаковський, Н. Стучинська, В. Шарко, М. Шут, М. Ігнатенко, Ю. Колягін, Ю. Мельник, $€$. Нелін, В. Пікан, Т. Заболотний, В. Сітарська. Питання підходу, орієнтованого на компетентність, стало популярним, але проблема полягала в тому, що різні автори визначали цей термін по-своєму. У цей період різними науковцями було запропоновано безліч визначень поняття компетенції та компетентності, запропоновано різні класифрікації компетенцій. При перекладі оригінальних текстів з англійської мови дуже часто терміни компетенція та компетентність не розрізнялись, що сприяло заплутаності та невизначеності термінологічного апарату. У свою чергу, ця невизначеність перешкоджала використанню цих понять для оцінки результатів навчання. Метою статті $\epsilon$ конкретизація змісту понять «компетенція» та «компетентність» у вітчизняній педагогічній галузі для подальшого використання в дослідженнях.

Методи та методики дослідження. Завдання визначення змісту понять компетенції та компетентності було вирішено багатьма дослідниками. Для висвітлення їх еволюції автори статті використовують метод порівняльно-історичного аналізу.

Результати та дискусії. Слово «компетенція» походить від латинського «competentia», що означає «добиваюся», «відповідаю», «підходжу», і формально використовується для визначення кола повноважень людини при характеристиці ії̈ прав та обов'язків [1]. Сьогодні поняття компетенції є ключовим терміном нормативно-правової літератури. Вважається, що в науковий дискурс термін «компетенція» було введено автором так званої генеративної граматики - Н. Хомським (США) у 1965 р. У своїй роботі він уперше дослідив принципову відмінність між компетентністю та знанням мови, між застосуванням та ії фрактичним використанням [2]. Цікаві філософрські та психологічні принципи цієї граматики сприяли тому, що термін «компетенція» дифундував в інші галузі наук. У табл. 1 наведено генезис використання слова в різних галузях суспільно-лінгвістичних знань у західній науковій думці.

У той же час, наприкінці 1960-х років як нова освітня тенденція почала формуватися компетентнісна освіта. Спочатку оригінальний лінгвістичний контекст компетенцій представляв інтерес для їх використанні в педагогічному та філософському експерименталізму. У цей час у педагогіці відбувалася трансфрормація поняття «компетенція» під впливом інших галузей знань. Пізніше, після запозичення терміну такими науками, як менеджмент, теорія управління, поняття компетенцій з'явилось у термінології опису ринку праці як фрорми оцінки людського капіталу або рівня профресійності працівників (Організації економічного співробітництва 
та розвитку (ОЕСР)). Так, у 2008 р. у світі з'явились перші Європейські рамки кваліфікації [3]. У них головними дескрипторами були компетенції. Система формальної освіти відповідала новим викликам суспільства щодо впровадження поняття компетенцій у стандарти оцінки знань студентів. Ідея була підтримана низкою впливових соціальних інститутів [4, 13]. 3 того часу почався процес синхронізації навчальних програм (робочих програм у 3ВО) відповідним рамкам національних кваліфікацій (НРК).

Таблиця 1

Генезис поняття компетенція в західному науковому дискурсі

\begin{tabular}{|c|c|c|c|c|}
\hline $\begin{array}{c}\text { Галузь } \\
\text { знань }\end{array}$ & Значення & Автори & $\begin{array}{c}\text { Перi } \\
\text { од } \\
\text { часу }\end{array}$ & Використання \\
\hline $\begin{array}{l}\text { філоло } \\
\text { гія }\end{array}$ & \begin{tabular}{lrr} 
мовна компетенція & - & це \\
система & уявлень & про \\
граматику & мови, \\
притаманні $\quad$ людин \\
народження; властиві & людині \\
як біологічному & виду \\
незалежно від його досвіду, \\
\multicolumn{2}{c}{ середовища існування }
\end{tabular} & $\begin{array}{l}\text { Л. Блумфілд, } \\
\text { 3. Харрис, } \\
\text { Ч. Хоккет, } \\
\text { генеративна } \\
\text { граматики } \\
\text { Н. Хомського }\end{array}$ & $\begin{array}{l}1950 \\
- \\
1960\end{array}$ & $\begin{array}{l}\text { Розуміння як } \\
\text { людина } \\
\text { засвоює мову } \\
\text { Навчання } \\
\text { студентів } \\
\text { іноземній мові } \\
\text { Лікування }\end{array}$ \\
\hline $\begin{array}{l}\text { менедж } \\
\text { мент }\end{array}$ & $\begin{array}{lr}\text { компетенції, } & \text { належать до } \\
\text { категорії } & \text { соціальних } \\
\text { конструктів, які } & \text { формуються } \\
\text { динамічною } & \text { соціальною } \\
\text { практикою і } & \text { підтримуються } \\
\text { різноманітними } & \text { соціальними } \\
\text { інститутам } & \end{array}$ & $\begin{array}{l}\text { Legge, } \\
\text { Becker \& } \\
\text { Gerhart, } \\
\text { Ulrich \& } \\
\text { Lake } \\
\text { Edvindsson } \\
\text { \& Malone } \\
\text { Hamel \& } \\
\text { Prahalad } \\
\text { 1994 }\end{array}$ & $\begin{array}{l}1990 \\
- \\
2000\end{array}$ & $\begin{array}{l}\text { захищати та } \\
\text { зміцнювати } \\
\text { операційні } \\
\text { можливості та } \\
\text { конкурентоспр } \\
\text { оможність } \\
\text { компанії за } \\
\text { допомогою } \\
\text { своєї бази } \\
\text { знань }\end{array}$ \\
\hline $\begin{array}{l}\text { юриспр } \\
\text { уденція }\end{array}$ & $\begin{array}{l}\text { відноситься до юридичної } \\
\text { «здатності» суду здійснювати } \\
\text { юрисдикцію щодо особи або } \\
\text { «речі» (майна), що є предметом } \\
\text { позову; має право приймати } \\
\text { певні рішення; } \\
\text { повноваження посадової особи } \\
\text { або органу (права та обов'язки) } \\
\text { за рішенням певного кола } \\
\text { питань (предмета відання). }\end{array}$ & $\begin{array}{l}\text { Perlin, M. } \\
\text { L., } \\
\text { Champine, } \\
\text { P., Dlugacz, } \\
\text { H. A., \& } \\
\text { Connell, }\end{array}$ & $\begin{array}{l}1900 \\
-\end{array}$ & $\begin{array}{l}\text { Вирішення } \\
\text { соціальних } \\
\text { конфліктів }\end{array}$ \\
\hline
\end{tabular}

Одними з найважливіших заходів у країнах Європейського простору у вищій освіті, спрямованій на впровадження НРК та компетентісного підходу до опису кваліфікацій на галузевому рівні, стало розроблення та реалізація галузевих рамок кваліфрікацій. Останні розробляються у сфері вищої освіти, мають описувати всі кваліфікації, здобуття яких є можливим у певній галузі освіти, зазначати загальні вимоги до результатів навчання для кожного кваліфрікаційного рівня в певній галузі та бути орієнтиром для створення стандартів вищої освіти й освітніх програм. 


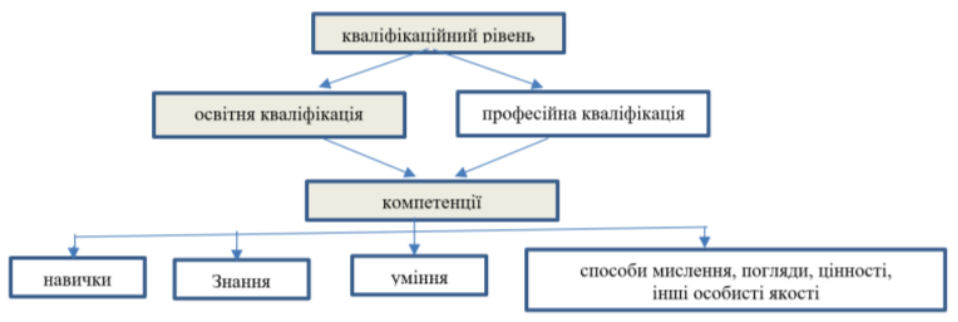

Puc. 1. Схема кваліфрікаційних рівнів освіти за [5]

В Україні після дискусії, що тривала з 2008 по 2010 рр., в 2011 р. Постановою КМУ № 1341 була затверджена Національна рамка кваліфікацій, у якій надано однозначне визначення компетенцій. Згідно з [5] Національна рамка кваліфрікацій $€$ ієрархією кваліфрікаційних рівнів. Затверджена в Україні НРК містить у собі опис десяти кваліфрікаційних рівнів (від 0 до 9), які охоплюють вітчизняну систему освіти. Ядром будьякого з 8 кваліфрікаційних рівнів $є$ відповідні компетенції (рис. 1). Компетенції НРК. визначені за допомогою дескрипторів: знання, уміння/навички, комунікація, відповідальність і автономія. У табл. 2 відповідно наведено опис 7-го кваліфікаційного рівня (рівень підготовки магістра).

Таблиця 2

Опис $7^{\text {го }}$ кваліфікаційного рівня НРК

\begin{tabular}{|c|c|c|c|}
\hline Знання & Уміння/навички & Комунікація & $\begin{array}{c}\text { Відповідальність } i \\
\text { автономія }\end{array}$ \\
\hline $\begin{array}{l}\text { спеціалізовані } \\
\text { концептуальні } \\
\text { знання, що } \\
\text { включають } \\
\text { сучасні } \\
\text { наукові } \\
\text { здобутки у } \\
\text { сфері } \\
\text { професійної } \\
\text { діяльності або } \\
\text { галузі знань і є } \\
\text { основою для } \\
\text { оригінального } \\
\text { мислення та } \\
\text { проведення } \\
\text { досліджень, } \\
\text { критичне } \\
\text { осмислення } \\
\text { проблем } \\
\text { галузі та на } \\
\text { межі галузей } \\
\text { знань }\end{array}$ & $\begin{array}{l}\text { спеціалізовані } \\
\text { уміння/навички } \\
\text { розв'язання проблем, } \\
\text { необхідні для } \\
\text { проведення досліджень } \\
\text { та/або провадження } \\
\text { інноваційної діяльності } \\
\text { з метою розвитку нових } \\
\text { знань та процедур; } \\
\text { здатність інтегрувати } \\
\text { знання та розв'язувати } \\
\text { складні задачі у } \\
\text { широких або } \\
\text { мультидисциплінарних } \\
\text { контекстах; здатність } \\
\text { розв'язувати проблеми } \\
\text { у нових умовах за } \\
\text { наявності неповної або } \\
\text { обмеженої інформації з } \\
\text { урахуванням аспектів } \\
\text { соціальної та етичної } \\
\text { відповідальності }\end{array}$ & $\begin{array}{l}\text { зрозуміле і } \\
\text { недвозначне } \\
\text { донесення } \\
\text { власних } \\
\text { знань, } \\
\text { висновків та } \\
\text { аргументації } \\
\text { до фахівців і } \\
\text { нефахівців, } \\
\text { зокрема до } \\
\text { осіб, які } \\
\text { навчаються }\end{array}$ & 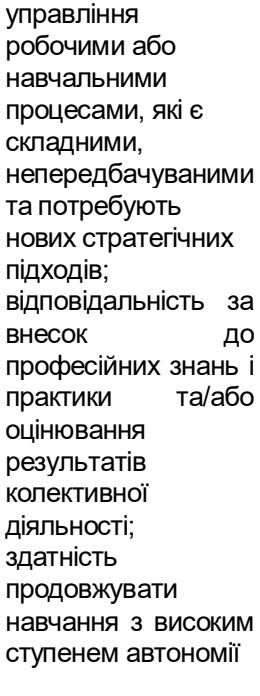 \\
\hline
\end{tabular}


У цілому, система дескрипторів української НРК узгоджується як з Європейською рамкою кваліфрікацій для навчання впродовж життя, так і з Рамкою кваліфікацій Європейського простору вищої освіти. Однак, у вітчизняну НРК додана так звана інтегральна компетентність (табл. 3).

Таблиця 3

Порівняння систем дескрипторів НРК та європейських рамок кваліфікації*

\begin{tabular}{|l|l|l|}
\hline $\begin{array}{c}\text { Європейська рамка } \\
\text { кваліфрікацій навчання } \\
\text { протягом життя }\end{array}$ & $\begin{array}{c}\text { Рамка кваліфікацій } \\
\text { Європейського } \\
\text { простору вищої освіти }\end{array}$ & \multicolumn{1}{|c|}{$\begin{array}{c}\text { Національна рамка } \\
\text { кваліфрікацій України }\end{array}$} \\
\hline Знання & Знання та розуміння & Знання \\
Уміння (когнітивні та & Застосування знань та & Уміння (когнітівні та \\
практичні) & розумінь & практичні) \\
Відповідальність та & Формування суджень & Комунікація \\
автономність & Комунікація & Автономність та \\
& Уміння навчатися & відповідальність \\
& & Інтегральна компетентність \\
\hline
\end{tabular}

Термін «компетентність», що використовується в повсякденному житті для характеристики ділових якостей людини, є синонімічним слову «професіоналізм» - здатності робити щось гарно «the ability to do something well» - the Oxford Advanced Learner's Dictionary [7]. У тeopiï управління введення концепції основної компетентності у 1990 році (від Прахалада та Хамеля) [8] та поява ідеї метакомпетентності [9] стали знаковою подією. Управлінці, менеджери, науковці дійшли висновку, що компетентність працівників - це стратегічне питання та воно цілісно пов'язано з економічним успіхом компанії. У словнику A Dictionary of Human Resource Management, виданому в Оксфорд [10], мета компетентності визначена як «загальні» компетенції, які мають відношення до широкого кола робочих умов та сприяють адаптації та гнучкості організації. Зазвичай кажуть, що «метакомпетентності включають навчання, адаптацію, передбачення та створення змін».

Визначення, надане вітчизняною Агенцією з класиффікації, повністю розкриває зміст терміну: «Компетентність - динамічна комбінація знань, умінь, навичок, способів мислення, поглядів, цінностей, інших особистих якостей, що визначає здатність особи успішно соціалізуватися, провадити професійну та/або подальшу навчальну діяльність» [5]. У національній системі освіти мета-компетенції відповідає інтегральна компетентність. Вона введена до НРК України (табл. 3) та відображає здатність особи, що має кваліфікацію певного рівня виконувати завдання та розв'язувати задачі певного рівня складності в процесі навчання або в професійній діяльності [6]. Інтегральні навички у НРК у загальному вигляді виражені через такі дескриптори: комунікація, відповідальність і автономія. Цей опис $є$ каркасом для створення ГРК, освітніх програм, відправною точку при пошуку методів навчання студентів, формування в них загальних та спеціальних (фахових, предметних) компетентностей. Загальні компетентності (ґрунтуються на поведінці) - це особисті характеристики, 
які сприяють ефрективній роботі (наприклад, міжособистісні навички, ставлення до роботи, цінності, мотивація).

Спеціальні компетенції (професійні) - це специфрічні навички та вміння, необхідні для діяльності відповідно до певних стандартів (наприклад, використання програмного забезпечення для електронних таблиць, вільне володіння англійською мовою, володіння навичками лапароскопії). Включення до стандартів освіти загальних компетентностей вважаємо важливим етапом у розвитку освіти (рис. 1). На відміну від попередніх систем оцінювання результатів навчання, коли моральні та особистості якості спеціаліста носили рекомендаційний характер, у стандарт включені інструменти для оцінки зрілості особистості, її можливості самовдосконалення та росту. Цей стандарт дуже важливий для професій, пов'язаних з роботою з людьми: лікарів, педагогів, соціальних робітників. Наприклад, введення до стандартів медичної освіти, обов'язкових соціальних компетенцій емпатії та гуманності, може вдосконалити професійний відбір та позитивно вплинути на розвиток галузі охорони здоров'я. Професійна готовність та професійна придатність мають встановлюватися 3 обов'язковим урахуванням морально-ціннісних якостей особистості.

Висновки. Компетентнісний підхід в освіті зосереджується на формуванні вмінь та розвитку якостей, необхідних для того, щоб спеціаліст був спроможний виконувати роботу відповідно до певних стандартів, прийнятих у сучасному суспільстві [12]. Ці стандарти відповідають кваліфрікаційним рівням освіти. I результати навчання, і присвоєні на їх основі кваліфрікації виражаються в термінах компетентностей. У подальших дослідженнях ми будемо притримуватися визначень, даних у HРК та законах України. Під компетенціями розуміється дескриптори рівня кваліфрікації спеціалістів. Компетентності - це результати навчання («динамічна комбінація знань, вмінь і практичних навичок, способів мислення, професійних, світоглядних і громадянських якостей, моральноетичних цінностей, яка визначає здатність особи успішно здійснювати професійну та подальшу навчальну діяльність і $€$ результатом навчання на певному рівні вищої освіти»), набуті в навчанні та можуть бути безпосередньо продемонстровані й оцінені. Компетентності включають не тільки знання та навички, але й морально-ціннісні якості особистості.

\section{Література}

1. Захарченко В. М., Міюсов М. В., Парменова Д. Г. Рамки кваліфікацій у Європейському освітньому просторі : навч.-метод. посіб. Одеса: НУ "ОМА», 2017. $88 \mathrm{c}$.

2. Постанова КМУ «Про затвердження Національної рамки кваліфікацій». Офріційний вісник України від 06.01.2012. № 101, с.15, стаття 3700 , код акта 59774/2011.

3. Словник іншомовних слів [за ред. О.С.Мельничука]. Головна редакція Української Радянської Енциклопедії АН УРСР. Киев, 1974. 
4. Стучинська Н.В. Формування фундаменту професійних компетентностей майбутніх лікарів у процесі навчання фрізико-математичних дисциплін // Наукові дослідження. Теорія та практика. С.71-74.

5. Хомский Н. Логические основы лингвистической теории. Новое 8 лингвистике. Вып. 4. Москва : Прогресс, 1965.

6. A Dictionary of Human Resource Management. Режим доступу: https://www.oxfordreference.com/view/10.1093/acref/9780199298761.001.0001/acref9780199298761.

7. ANNEX to the Proposal for a Council Recommendation on Key Competences for Lifelong Learning [Electronic resource]. URL: https://ec.europa.eu/education/sites/education/files/annex-recommendation-keycompetences-lifelong-learning.pdf.

8. Competence is not enough: meta-competence and accounting education. Brown RB, S McCartney. Accounting Education 4 (1), 43-53, 1995.

9. Hamel G., Prahalad C. K. (1996). Competing for the future. Boston, Mass, Harvard Business School Press.

10. Oxford Advanced Learner's Dictionary. URL: https://www.oxfordlearnersdictionaries.com.

11. OECD (2005) The definition and selection of key competencies. Executive Summary. Paris: OECD. p. 4. URL: www.oecd.org/pisa/35070367.pdf

12. Quality education and competencies for life / Workshop 3/ Background Paper, 2004. p. 6.

13. Recommendation of the European Parliament and of the Council of 23 April 2008 on the establishment of the European Qualifications Framework for lifelong learning (2008/C 111/01). Official Journal of the EU, 6.5.2008. C.111/4.

\section{References:}

1. Zaharchenko V.M., Miyusov M.V., Parmenova D.G. (2017) Ramki kvalifikacij u Evropejs'komu osvitn'omu prostori. [Navchal'no-metodichnij posibnik]. Odesa: NU «OMA» (p. 88) [in Ukrainian].

2. Postanova KMU (2012) «Pro zatverdzhennya Nacional'noï ramki kvalifikacij» [Oficijnij visnik Ukraïni] vid 06.01.2012, № 101, (p.15), stattya 3700, kod akta 59774/2011 [in Ukrainian].

3. Slovnik inshomovnih sliv (1974) [Za redakcieyu O. S. Mel'nichuka, Golovna redakciya Ukraïns'koï Radyans'koï Enciklopediï AN URSR. ] Kiev [in Ukrainian].

4. Stuchins'ka N. V. Formuvannya fundamentu profesijnih kompetentnostej majbutnih likariv u procesi navchannya fiziko-matematichnih disciplin [Nauchnii yssledovanyia. Teoryia y praktyka] (p.71-74) [in Ukrainian].

5. Homskij N. (1965) Logicheskie osnovy lingvisticheskoj teorii [Novoe v lingvistike] M.: Progress - (4) (p.590) [in Ukrainian].

6. A Dictionary of Human Resource Management. [Electronic resource] URL: https://www.oxfordreference.com/view/10.1093/acref/9780199298761/acref-97801761 [in English].

7. ANNEX to the Proposal for a Council Recommendation on Key Competences for Lifelong Learning (2015) [Electronic resource]. URL: https://ec.europa.eu/education/sites/education/files/annex-recommendation-keycompetences-lifelong-learning.pdf [in English].

8. Brown RB, McCartney $S$ (1995) Competence is not enough: metacompetence and accounting education. [ Accounting Education]. 4 (1), (p.43-53) [in English]. 
9. Hamel, G., Prahalad C. K. (1996). Competing for the future. [Boston, Mass], Harvard Business School Press [in English].

10. Oxford Advanced Learner's Dictionary. [Electronic resource] Rezhim dostupu: https://www.oxfordlearnersdictionaries.com/ [in English].

11. OECD (2005) The definition and selection of key competencies. [Executive Summary. ] Paris: OECD.( r. 4). (Rezhim dostupu: www.oecd.org/pisa/35070367.pdf) /.[in English].

12. Quality education and competencies for life (2004) [Workshop 3/ Background Paper] (p. 6) [in English].

13. Recommendation of the European Parliament and of the Council of 23 April 2008 on the establishment of the European Qualifications Framework for lifelong learning (2008/C 111/01) [ Official Journal of the EU] (p. 111/4) [in English].

\section{АНОТАЦІЯ}

У статті досліджено розвиток компетентісного підходу в системі вищої профресійної освіти України. Для конкретизації змісту понять «компетенція» та «компетентність» в рамках цього підходу у вітчизняній педагогічній галузі використано метод порівняльно-історичного аналізу, за допомогою якого проаналізовано роботи вітчизняних учених у період становлення компетентнісного підходу. Розглянуті праці українських науковців різних галузей знань: фрілологія, менеджмент, теорія управління та управління персоналом, право, педагогіка. Досліджена хронологія появи поняття «компетенція» в західній науковій думці, розвиток та трансформація його в освітній стандарт. Для поглибленого розуміння поняття «компетентність» проаналізовано процес появи терміну в нормативній базі України, генезис перетворення їі в стандарт вищої освіти на вітчизняних теренах. Описана структура кваліфікаційних рівнів Національної рамки кваліфікацій. Визначені основні дескриптори Національної рамки кваліфікацій: знання, уміння (когнітівні та практичні), комунікація, автономність та відповідальність, інтегральна компетентність. У статті надається порівняння системи дескрипторів української Національної рамки кваліфікацій 3 Європейською рамкою кваліфрікацій для навчання впродовж життя, Рамкою кваліфікацій Європейського простору вищої освіти. Розкрита сутність компетенцій та компетентності як складників опису кваліфрікацій у Національній рамці кваліфрікацій. Виокремлені відмінності компетенцій від попередніх показників оцінки якості навчання. Визначені особливості інтегральних компетентностей як таких, що відображають здатність особи, що має кваліфікацію певного рівня, виконувати завдання та розв'язувати задачі певного рівня складності в процесі навчання або у професійній діяльності. Розглянуті загальні компетентності як інструменти для оцінки зрілості особистості, їі можливості самовдосконалення та росту. Підкреслено, що професійна готовність та професійна придатність мають встановлюватися з обов'язковим урахуванням морально-ціннісних якостей особистості. Запропоновані загальні компетентності, які можуть удосконалити професійний відбір та позитивно вплинути на розвиток галузі охорони здоров'я.

Ключові слова: компетенція, компетентності, вища освіта, результати навчання, компетентнісний підхід, національні рамки кваліфрікацій, галузеві рамки кваліфікації. 